\title{
En kvinne i 50-årene med tungpustethet og hypotensjon
}

\author{
Tungpustethet og nedsatt fysisk yteevne er vanlige symptomer ved \\ sykehusinnleggelse. Oftest er årsaken til disse symptomene vanlige \\ hjerte- eller lungesykdommer, men av og til ligger sjeldnere sykdom- \\ mer bak, sykdommer som ikke alltid diagnostiseres ved vanlig utred- \\ ning.
}

En kvinne i 50-årene med kjent medikamentelt behandlet hypotyreose, fibromyalgi og revmatoid artritt ble innlagt i lokalsykehus etter fire ukers sykehistorie med tiltakende tungpustethet, generelt redusert fysisk yteevne, hoste, feberfølelse, nattesvette samt smerter i thorax og ut i venstre skulder. Hun hadde hatt tre innleggelser i revmatologisk avdeling de siste 3-4 månedene før denne innleggelsen på grunn av omfattende smerteproblematikk.

Det var startet med tumornekrosefaktor$\alpha$-hemmer i tillegg til behandling med metotreksat, selv om den revmatologiske sykdomsaktiviteten ble vurdert å være lav. Den siste uken før innleggelsen hadde hun knapt orket å gå ut av leiligheten sin. Det ble før innleggelsen startet med behandling med fenoksymetylpenicillin på grunn av mistenkt luftveisinfeksjon, uten at dette hadde effekt på symptomene. Røntgen thorax tatt før innleggelsen viste betydelig økt hjertestørrelse, og blodtrykket var kun $84 / 60 \mathrm{~mm} \mathrm{Hg}$. Innleggelsesdiagnosen var derfor hjertesvikt.

Ved innleggelsen ble allmenntilstanden vurdert å være lett redusert. Pasienten hadde ubesværet respirasjon i hvile og ingen perifere ødemer. Blodtrykket var hele tiden lavt, på det laveste $89 / 64 \mathrm{~mm} \mathrm{Hg}$. Pasienten var lett takykard. EKG viste sinustakykardi med lave QRS-komplekser i standardavledningene. Hjertetonene var noe svake, og det var knatrelyder basalt over venstre lungebakflate. Pasienten var afebril og hadde perifer oksygenmetning på $94 \%$.

Pasienten hadde altså en tilstand som både påvirket allmenntilstanden og ga henne nedsatt fysisk yteevne og tungpustethet ved anstrengelse. En nedre luftveisinfeksjon kunne ha vært årsak til symptomene. Behandling med fenoksymetylpenicillin hadde ikke bedret tilstanden, men slik behandling har ingen effekt på de fleste gramnegative bakterier, atypiske bakterier og virus. Den betydelige hjerteforstørrelsen som var sett på røntgen thorax før innleggelsen, kunne imidlertid ikke forklares med en luftveisinfeksjon alene.
Hjertesvikt var en annen mulig diagnose, men hjertesvikt i seg selv gir ikke påvirket allmenntilstand med feberfølelse og nattesvette. Infeksiøs eller inflammatorisk myokarditt var derimot en mulig årsak som kunne forklare både hjertesviktsymptomene, allmennsymptomene og hvorfor pasienten hadde smerter $i$ thorax og ut i venstre skulder. Pasienten hadde i tillegg lavt blodtrykk og lave QRS-komplekser i standardavledningene på EKG. Sammen med røntgenfunnene kunne dette gi mistanke om perikardaffeksjon med perikardvæske og truende hjertetamponade, noe som er en alvorlig tilstand.

Blodprøver viste økte inflammasjonsmarkører, med senkningsreaksjon (SR) på $87 \mathrm{~mm}$ $(2-10 \mathrm{~mm})$ og C-reaktivt protein (CRP) på $204 \mathrm{mg} / \mathrm{l}(0-10 \mathrm{mg} / \mathrm{l})$. Hvite blodceller var normale på $8,4 \cdot 10^{9}\left(3,5-10,0 \cdot 10^{9}\right)$. Troponin $T$-verdien var normal $<10 \mathrm{ng} / \mathrm{l})$, mens prohjernenatriuretisk peptid (BNP) kun var lett forhøyet $-41 \mathrm{pmol} / \mathrm{l}(0-35 \mathrm{pmol} / \mathrm{ll}$. Stoffskifteprøver og kreatinin var normale. Revmatoid faktor-lgA var forhøyet - $29 \mathrm{IU} / \mathrm{ml}$ (< $25 \mathrm{lU} / \mathrm{ml}$.

Røntgen thorax ga mistanke om perikardvæske (fig 1a). Dette ble verifisert ved ekkokardiografi, som viste væske i perikard rundt store deler av hjertet, med største bredde på $2,5 \mathrm{~cm}$ bak venstre ventrikkel. Venstre ventrikkel hadde gode kontraksjoner $i$ alle avsnitt, noe som sammen med normale troponin T-verdier talte imot myokarditt. Imidlertid var høyre ventrikkels funksjon litt redusert, og det ble bemerket at høyre sides laterale vegg var fortykket. Pasienten ble dagen etter innleggelsen overført til regionsykehus på grunn av mistanke om truende hjertetamponade og ble tappet for $1200 \mathrm{ml}$ blodtilblandet perikardvæske.

Den patologiske mengden perikardvæske kunne forklare pasientens hjertesviktsymptomer. Årsaker til økt mengde perikardvæske kan være infeksjon, ikke-infeksiøs inflammasjon, malignitet, metabolsk (uremi, myksødem), tidligere bestråling, direkte traume, hjerteinfarkt, hjerteoperasjon/-inter-

\author{
Anders Hommerstad* \\ anders.hommerstad@gmail.com \\ Medisinsk avdeling \\ Diakonhjemmet Sykehus \\ Kirsten Sundby Hall \\ Avdeling for kreftbehandling \\ Oslo universitetssykehus, Radiumhospitalet

\section{Bodil Bjerkehagen} \\ Avdeling for patologi \\ Oslo universitetssykehus, Radiumhospitalet \\ Trond H. Eskild \\ Radiologisk avdeling \\ Diakonhjemmet Sykehus \\ Odd Geiran \\ Thoraxkirurgisk avdeling, \\ Oslo universitetssykehus, Rikshospitalet \\ Erik Øie \\ Medisinsk avdeling, \\ Diakonhjemmet Sykehus
}

* Nåværende adresse:

Medisinsk avdeling

Oslo universitetssykehus, Ullevål 
vensjon, medikamentell eller hemodynamisk (hjertesvikt, pulmonal hypertensjon, hypoalbuminemi). Perikardiocentese utføres ofte som behandling og for å kunne stille korrekt diagnose.

Vi anså at de mest sannsynlige differensialdiagnostiske årsakene til perikardvæsken var infeksjon (på grunn av høy SR og CRP), ikke-infeksiøs inflammasjon (på grunn av høy SR og CRP samt kjent revmatoid artritt) eller malignitet (på grunn av høy SR og CRP samt blodig perikardvæske). Normale stoffskifteprøver og kreatininnivået talte imot metabolsk årsak. Tilstanden ble initialt tolket som perikarditt med ukjent genese, muligens på grunn av hennes revmatoide artritt.

På grunn av den forhøyede CRP-verdien ble det for sikkerhets skyld startet behandling med ceftriakson intravenøst, i påvente av dyrkningssvar fra perikardvæsken. Pasienten ble skrevet ut ti dager etter primærinnleggelsen i lokalsykehus med daglige intramuskulære ceftriaksoninjeksjoner poliklinisk. Allmenntilstanden ble raskt bedre, og CRP-nivået falt til $40 \mathrm{mg} / \mathrm{l}$ én uke etter at pasienten ble innlagt.

Bakteriell årsak til perikardvæske er sjeldent, bortsett fra i land med endemisk tuberkulose (1). Viral årsak er sannsynligvis mer vanlig. Systemisk inflammatorisk sykdom som revmatoid artritt, slik vår pasient hadde, kan også føre til forhøyet CRP-nivå og økt mengde perikardvæske. Man kan derfor stille spørsmål ved om det var riktig å starte med antibiotika.

Seks dager etter utskrivning og 16 dager etter første innleggelse ble pasienten reinnlagt i lokalsykehuset på grunn av raskt forverret allmenntilstand. SR var nå $63 \mathrm{~mm}$, CRP $32 \mathrm{mg} / \mathrm{l}$ og hvite blodceller 2,7.10\% $\mathrm{l}$. Det var kommet svar på prøvene - det var ikke patologiske funn ved cytologisk, biokjemisk eller bakteriologisk undersøkelse av perikardvæsken.

Pasienten ble denne gang utredet med CT thorax, som viste en oppfylling i høyre forkammer (fig 1b). Denne ble gjenfunnet ved transtorakal ekkokardiografi (fig 1c). Videre utredning med transøsofageal ekkokardiografi viste en bredbaset oppfylling i høyre forkammer på $5,1 \mathrm{~cm} \times 5,7 \mathrm{~cm}$ (fig 1d). Pasienten ble overført til regionsykehus for nærmere diagnostisering av oppfyllingen.

Svulster i hjertet er svært sjeldent $(0,002$ $0,03 \%$ av uselekterte pasienter i store obduksjonsmaterialer) $(2,3) .80-90 \%$ av alle svulster i hjertet er godartet (4). Av de godartede svulstene er myksomer vanligst hos voksne (ca. $75 \%$ ). De maligne svulstene i hjertet er 20-40 ganger hyppigere metastaser fra andre organer enn primære maligne svulster - vanligst er adenokarsinomer, maligne melanomer eller sarkomer (5-7).

De primære maligne svulstene i hjertet utgjøres av ulike sarkomer, for eksempel angiosarkom. Av 30 pasienter med tumor i hjertet operert ved Thoraxkirurgisk avdeling ved Rikshospitalet i perioden 1990-99 hadde 27 benign tumor, hvorav 25 hadde myksom, mens én pasient hadde rabdomyosarkom og to pasienter metastaser (8). Siden år 2000 er ni pasienter med sarkom i hjertet blitt behandlet ved Oslo universitetssykehus, hvorav to med angiosarkom (upubliserte data fra Kvalitetsregisteret for sarkomer, Oslo universitetssykehus, v/KSH).

Histologisk og immunhistokjemisk undersøkelse av tumorvevet viste et lite differensiert spolcellet tumorvev som var kraftig positivt for CD31, som er en sensitiv markør for endotel, forenlig med angiosarkom (fig 2).

Angiosarkomer oppdages ofte ved ekkokardiografisk undersøkelse eller CT thorax, slik som hos vår pasient. Ved ekkokardiografi fremstår sarkomer ofte som en inhomogen masse som er annerledes enn den man ser ved myksomer (9).

CT- og MR-undersøkelse er verdifull bildediagnostikk for å kartlegge størrelsen av tumor og hvilke strukturer i hjertet som er involvert. Kombinasjonen av ekkokardiografi og CT/MR gir et godt utgangspunkt for planlegging av operasjon. Endelig diagnose av svulstvevet gjøres ved histologisk, immunhistokjemisk og eventuell genetisk undersøkelse.

Pasienten fikk neoadjuvant kjemoterapi med doksorubicin og ifosfamid før hun ble operert med reseksjon av høyre atrievegg med sarkom. Det var knappe, men frie reseksjonsrender histologisk. Det ble deretter gitt adjuvant kjemoterapi med doksorubicin og ifosfamid (tre kurer) og gemcitabin/docetaksel (fire kurer), avslutningsvis strålebehandling (50 Gy) mot hjertet.

Hun ble deretter fulgt poliklinisk med regelmessige kontroller med transtorakal ekkokardiografi ved lokalsykehuset og ved kreftavdeling ved regionsykehus. Hun fikk ett år etter første innleggelse nedsatt allmenntilstand og redusert fysisk yteevne med moderat forhøyet CRP-verdi på $36 \mathrm{mg} / \mathrm{l}$ og betydelig forhøyet senkningsreaksjon på $104 \mathrm{~mm}$. CT thorax viste nye fibroseforandringer i høyre lunge. Tilstanden ble oppfattet som stråleindusert lungefibrose, og pasienten ble behandlet med prednisolon. Den kliniske tilstanden bedret seg raskt, med normalisering av inflammasjonsmarkørene.

Tre år etter at sarkomet ble diagnostisert, ble det påvist metastasesuspekt tumor
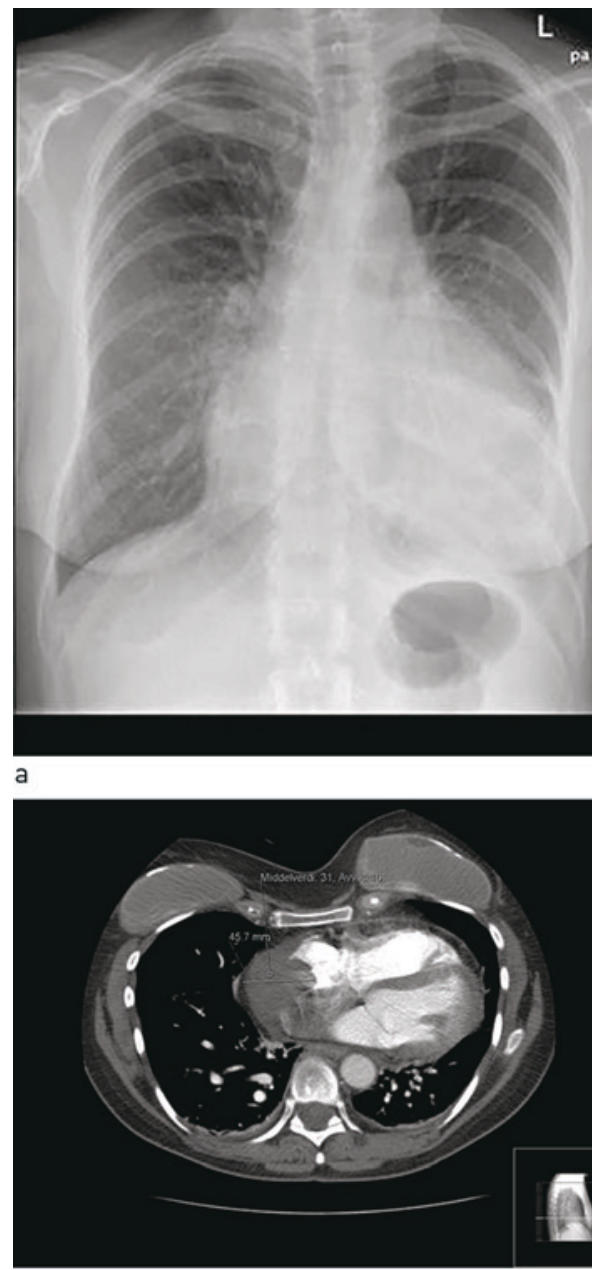

b
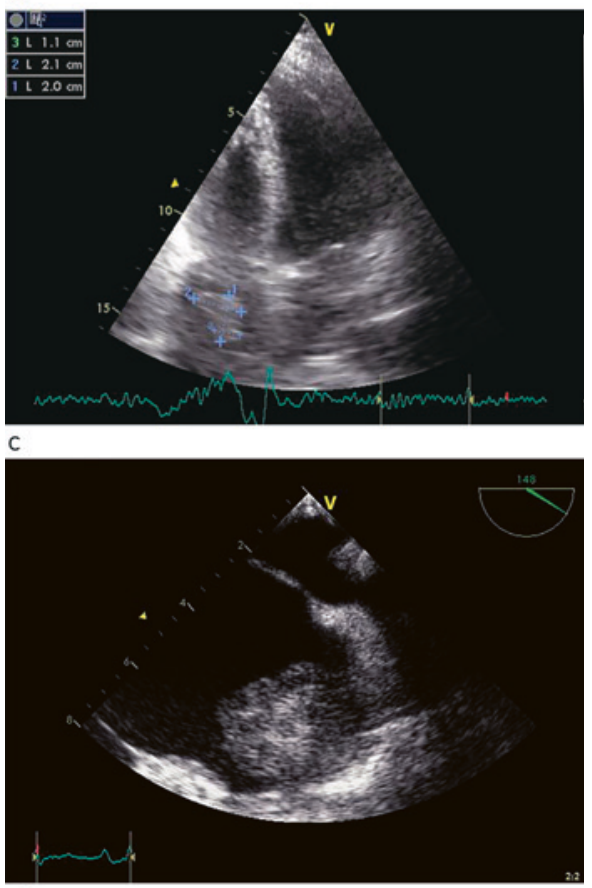

Figur 1 a) Røntgen thorax viste stort hjerte med mistanke om perikardvæske. b) Tumor i høyre for kammer vist på CT, c) transtorakal ekkokardiografiog d) transøsofageal ekkokardiografi 


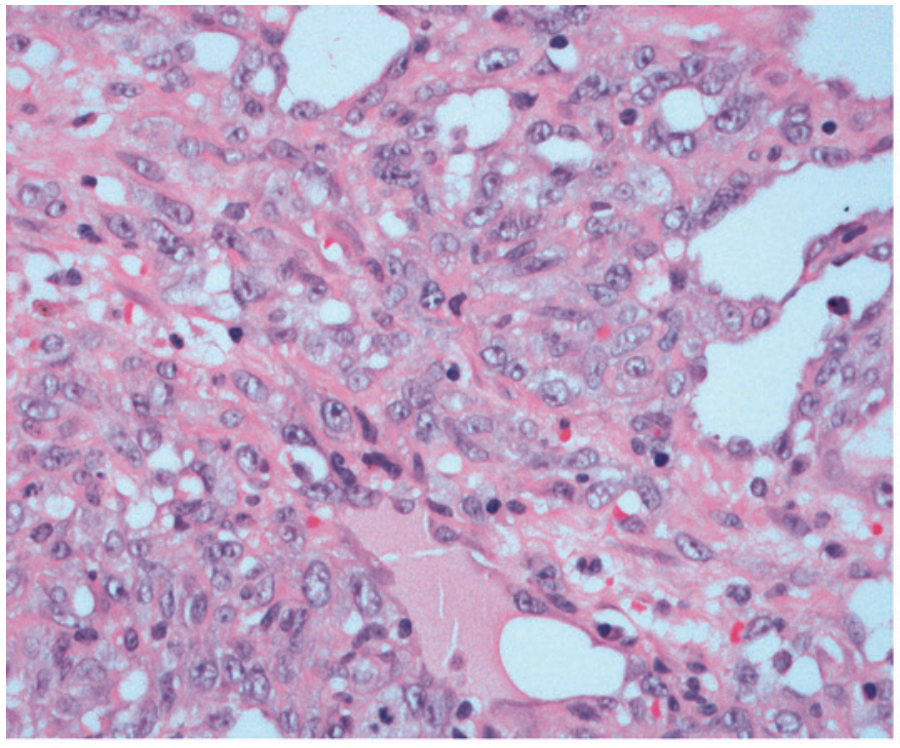

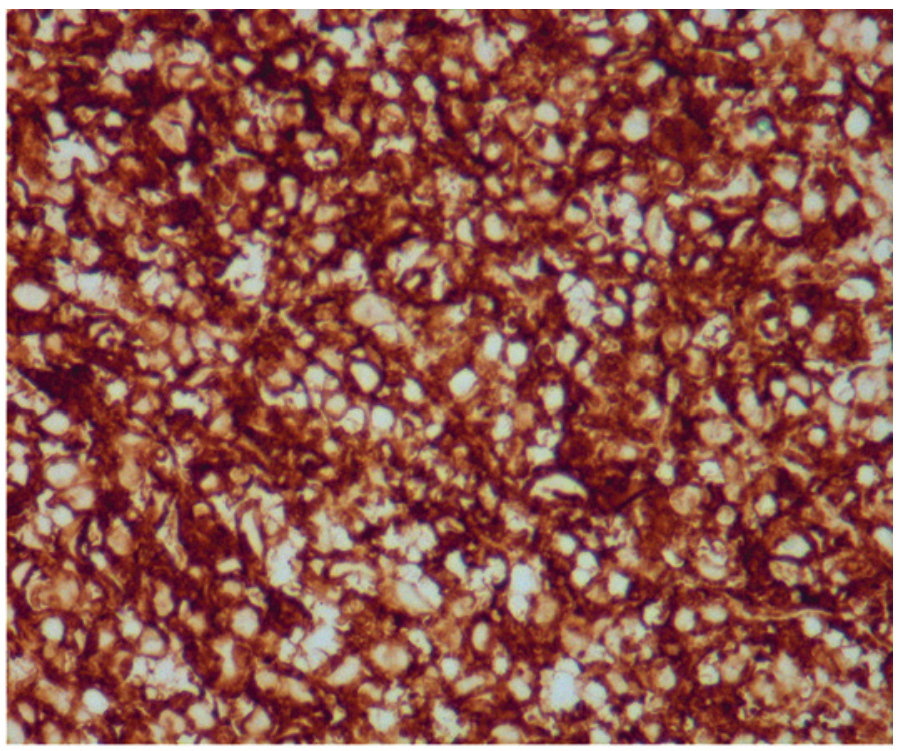

Figur 2 a) Mikroskopisk undersøkelse viste karstrukturer kledd av atypisk endotel, forenlig med angiosarkom (hematoksylin- og eosinfarget tumorvev), mens b) immunhistokjemisk undersøkelse av tumorvev viste positivt funn for endotelmarkøren CD31

venstre ventrikkel. Den var sannsynligvis en spredning fra primærtumor, og den ble vurdert som ikke tilgjengelig for kirurgi eller strålebehandling. Det ble derfor startet behandling med tyrosinkinasehemmeren pazopanib, et nokså nytt medikament som nå er godkjent for behandling av pasienter med avansert bløtvevssarkom. Det har relativt lav bivirkningsfrekvens. Pasienten døde sju måneder senere, 3,5 år etter at diagnosen første gang ble stilt.

\section{Diskusjon}

Angiosarkom er den vanligste formen for primær malign neoplasi i hjertet $(4,10)$. Primært sarkom i hjertet er likevel en svært sjelden tilstand. Frem til år 2000 var bare 300 tilfeller med angiosarkom utgående fra hjertet beskrevet i litteraturen (11).

I løpet av tre år diagnostiserte vi sarkom i høyre forkammer hos ytterligere to pasienter, én med angiosarkom og én med et udifferensiert sarkom. Begge pasientene var blitt innlagt på grunn av vanlige symptomer som brystsmerte og tungpustethet. Hos to av de tre pasientene hadde førstegangsinnleggelse i både lokalsykehus og regionsykehus ikke avdekket oppfyllingen i høyre atrium. Diagnosen ble mistenkt etter gjentatte transtorakale ekkokardiografier eller CT thorax. Dette illustrerer at det kan være vanskelig å oppdage patologiske forhold i høyre forkammer ved transtorakal ekkokardiografisk undersøkelse hvis man ikke spesielt ser etter det.

Tre pasienter diagnostisert med sarkom i høyre forkammer fra samme lokalsykehus, derav to med angiosarkom, over en tidsperiode på tre år er spesielt. Bedre bildedia- gnostikk kan være én årsak til at man lettere diagnostiserer denne tilstanden, som har en prevalens på $0,0017 \%$ i obduksjonsmaterialer (12). Insidensen varierer fra $0,001 \%$ til $0,03 \%(13)$.

Det er i de senere årene blitt publisert flere oppdaterte gjennomganger av tilstanden og dens behandling $(10,14)$. De fleste angiosarkomer i hjertet er, som hos våre pasienter, lokalisert i høyre forkammer $(15,16)$. Ved diagnosetidspunktet har de fleste pasienter symptomer. Angiosarkom utgående fra høyre forkammer gir ofte pulmonal hypertensjon med symptomer som ortopné og lungeødem, ved siden av feber, arytmier, brystsmerter og perikardeffusjon. Det er rapportert at to tredeler av pasientene har hjertesvikt i NYHAfunksjonsklasse III eller IV ved diagnosetidspunktet $(10,14)$.

Median total overlevelse for pasienter med kardialt sarkom var i en stor epidemiologisk studie seks måneder, sammenliknet med 93 måneder for pasienter med sarkom utenfor hjertet (10). Vi har ikke funnet randomiserte studier der man har undersøkt effekten av behandling av angiosarkom i hjertet, og det er vel heller ikke å forvente på grunn av den svært lave insidensen.

Ved Mayo-klinikken i USA ble det i 2008 gjort en retrospektiv gjennomgang av operativ behandling av angiosarkomer gjennom 34 år, til sammen 32 operasjoner. Median overlevelse var 17 måneder etter total reseksjon sammenliknet med 12 måneder etter subtotal reseksjon (17). I en retrospektiv gjennomgang av 27 pasienter med primært sarkom i hjertet fra to sentre i USA fra perioden 1990-2005, hvor det ble gjennomført reseksjon av både primærtumor og metastaser samt gitt adjuvant kjemo- eller radioterapi, var to tredeler av pasientene i live etter to år (18). Dette er bedre overlevelse enn rapportert i tidligere materialer (19).

Total reseksjon er vanskelig å gjennomføre ved diffus innvekst $\mathrm{i}$ omkringliggende vev eller ved lokalisasjoner i hjertet som krever komplisert rekonstruksjon. Andre data fra samme forskningsgruppe tyder på at prognosen etter kirurgisk behandling av sarkomer i høyre hjertehalvdel er dårligere enn etter inngrep ved sarkomer utgående fra venstre hjertehalvdel og pulmonalarterien, sannsynligvis fordi sarkomer i høyre hjertehalvdel har en mer infiltrerende vekst slik at det er vanskeligere å oppnå total reseksjon (20).

Alle pasienter hvor sarkom i hjertet kan mistenkes, skal henvises til et sarkomsenter, og utredning, biopsitilgang og behandling skal diskuteres i tverrfaglig sarkomgruppe. Våre pasienter fikk preoperative cytostatikakurer for å skrumpe tumor slik at frie marginer skulle kunne oppnås ved kirurgi. Dette ble kun oppnådd hos én av pasientene. Fra 1998 har man i USA utført autotransplantasjoner der eksisjon av tumor blir utført ex vivo for lettere tilgang ved komplisert lokalisering av tumor (19).

Adjuvant kjemoterapi gis ofte etter eksisjon av angiosarkomer i hjertet, selv om det ikke foreligger randomiserte studier som understøtter nytten av dette. Man bruker liknende behandlingsprotokoller som for andre bløtdelssarkomer. I en studie som inkluderte 15 pasienter som ble operert med total og subtotal reseksjon og deretter gitt adjuvant kjemoterapi (doksorubicin), var median over- 
levelse 12 måneder og effekten av kjemoterapien usikker (21). Det er også usikker effekt av strålebehandling.

Den viktigste behandlingen av disse aggressive svulstene er radikal kirurgi, slik som ved bløtvevssarkomer for øvrig. Det er viktig å følge opp disse pasientene, da de kan få redusert ventrikkelfunksjon og stråleindusert lungeskade, siden man ofte ikke kan unngå å få noe lungevev med i strålefeltet (22).

Pasientene eller pårørende til pasientene som omtales, har gitt samtykke til at artikkelen blir publisert.

\section{Anders Hommerstad (f. 1974)}

er lege i spesialisering i hjertesykdommer. Forfatter har fylt ut ICMJE-skjemaet og oppgir ingen interessekonflikter.

\section{Kirsten Sundby Hall (f. 1951)}

er spesialist i onkologi og i medisinsk biokjemi og overlege.

Forfatter har fylt ut ICMJE-skjemaet og oppgir ingen interessekonflikter.

\section{Bodil Bjerkehagen (f. 1959)}

er spesialist i patologi og overlege.

Forfatter har fylt ut ICMJE-skjemaet og oppgir ingen interessekonflikter.

\section{Trond H. Eskild (f. 1958)}

er spesialist i radiologi og overlege.

Forfatter har fylt ut ICMJE-skjemaet og oppgir ingen interessekonflikter.

\section{Odd Geiran (f. 1943)}

er spesialist i generell kirurgi, i thoraxkirurgi og i karkirurgi.

Forfatter har fylt ut ICMJE-skjemaet og oppgir ingen interessekonflikter.

\section{Erik Øie (f. 1967)}

er spesialist i indremedisin og i hjertesykdommer og er seksjonsoverlege.

Forfatter har fylt ut ICMJE-skjemaet og oppgir ingen interessekonflikter.

\section{Litteratur}

1. Imazio M, Adler Y. Management of pericardial effusion. Eur Heart J 2013; 34: 1186-97.

2. Reynen K. Frequency of primary tumors of the heart. Am J Cardiol 1996: 77. 107.

3. Lam KY, Dickens P. Chan AC. Tumors of the heart. A 20 -year experience with a review of 12,485 consecutive autopsies. Arch Pathol Lab Med 1993; 117: 1027-31.

4. Travis WD, Brambilla E, Muller Hermelink HK et al. red. World Health Organization classification of tumours. Pathology and genetics of tumours of the ung, pleura, thymys and heart. Lyon: IARC Press, 2004

5. Cina SJ, Smialek JE, Burke AP et al. Primary cardiac tumors causing sudden death: a review of the literature. Am J Forensic Med Pathol 1996: 17: 271-81.

6. Bear PA, Moodie DS. Malignant primary cardiac tumors. The Cleveland Clinic experience, 1956 to 1986. Chest 1987; 92: 860-2

7. Blondeau P. Primary cardiac tumors-French studies of 533 cases. Thorac Cardiovasc Surg 1990: 38 (suppl 2): 192-5

8. Baksaas ST, Geiran OR, Svennevig JL. Svulster i hjertet. Tidsskr Nor Lægeforen 2000; 120 2391-3

9. Edwards LC 3rd, Louie EK. Transthoracic and transesophageal echocardiography for the evaluation of cardiac tumors, thrombi, and valvular vegetations. Am J Card Imaging 1994: 8: 45-58.
10. Hamidi M, Moody JS, Weigel TL et al. Primary cardiac sarcoma. Ann Thorac Surg 2010: 90: 176-81.

11. Butany J, Yu W. Cardiac angiosarcoma: two cases and a review of the literature. Can J Cardiol 2000; 16: 197-205

12. Straus R, Merliss R. Primary tumor of the heart. Arch Pathol (Chic) 1945: 39: 74-8.

13. McAllister H, Fenoglio JJ. Tumors of the cardiovascular system. Atlas of Tumor Pathology. Fascicle 15, Second Series. Washington D.C.: Armed Forces Institute of Pathology, 1978: 1-3.

14. Orlandi A, Ferlosio A, Roselli M et al. Cardiac sarcomas: an update. J Thorac Oncol 2010; 5: 1483-9.

15. Burke AP, Cowan D, Virmani R. Primary sarcomas of the heart. Cancer 1992; 69: 387-95.

16. Glancy DL, Morales JB Jr, Roberts WC Angiosarcoma of the heart. Am J Cardiol 1968; 21: 413-9.

17. Simpson L, Kumar SK, Okuno SH et al. Malignant primary cardiac tumors: review of a single institution experience. Cancer 2008; 112: 2440-6.

18. Bakaeen FG Jaroszewski DE Rice DC et al Outcomes after surgical resection of cardiac sarcoma in the multimodality treatment era. J Thorac Cardiovasc Surg 2009; 137: 1454-60.

19. Bakaeen FG, Reardon MJ, Coselli JS et al. Surgical outcome in 85 patients with primary cardiac tumors. Am J Surg 2003; 186: 641-7.

20. Kim MP, Correa AM, Blackmon S et al. Outcomes after right-side heart sarcoma resection. Ann Thorac Surg 2011: 91: 770-6.

21. Llombart-Cussac A, Pivot X, Contesso G et al. Adjuvant chemotherapy for primary cardiac sarcomas: the IGR experience. Br J Cancer 1998; 78: $1624-8$.

22. Rosen EM, Fan S, Rockwell S et al. The molecular and cellular basis of radiosensitivity: implications for understanding how normal tissues and tumor respond to therapeutic radiation. Cancer Invest 1999; 17: 56-72.

Mottatt 2.9. 2013, første revisjon innsendt 24.1. 2014, godkjent 26.6. 2014. Redaktør: Are Brean. 